\title{
STABILITASI MONETER MELALUI INSTRUMEN AL-KHARJ DAN RELEVANSINYA DI INDONESIA MENURUT ABU YUSUF
}

\section{MONETARY STABILITY THROUGH AL-KHARJ INSTRUMENTS AND ITS RELEVANCE IN INDONESIA BY ABU YUSUF}

\author{
Syamsuri1a; Nunik Nursiha²; Suyoto Arief ${ }^{3}$
}

1aDarussalam Gontor University, Jl. Raya Siman No.Km. 6, Dusun I, Siman, Kec. Siman, Kabupaten Ponorogo, Jawa Timur 63471, e-mail: syamsuri@unida.gontor.ac.id ${ }^{2}$ Darussalam Gontor University, Jl. Raya Siman No.Km. 6, Dusun I, Siman, Kec. Siman, Kabupaten Ponorogo, Jawa Timur 63471, e-mail: nunik@unida.gontor.ac.id

${ }^{3}$ Darussalam Gontor University, Jl. Raya Siman No.Km. 6, Dusun I, Siman, Kec. Siman, Kabupaten Ponorogo, Jawa Timur 63471, e-mail; yosa@unida.gontor.ac.id

\begin{abstract}
One of the most important tasks the government must carry out, especially in the economic sector, is achieving economic stability. Because the achievement of economic stability is able to facilitate the running of economic development activities. In this task, not only fiscal policy but monetary policy also plays a role. Al-Kharj (tax) which is a fiscal policy has a stability function, where tax funds are used for price stability in suppressing inflation. Taxes are mandatory contributions paid to the State that are owed by individuals or entities that are compelling. If this policy instrument is implemented properly, the input will be large. Abu Yusuf Ya'qub is one of the scientists who contributed greatly to Islamic economic thought. One of the thoughts he wrote in his book Al-Kharaj is an indication of how to manage a good and true tax to achieve the well-being of the people. It is necessary to review how Abu Yusuf thought about Al-Kharj instrument in monetary stability and its relevance in Indonesia.
\end{abstract}

Keywords: Al-Kharj, Abu Yusuf Thought, Monetary Stability, Tax Relevance

\section{ABSTRAK}

Salah satu tugas terpenting pemerintah yang harus diemban khususnya di bidang ekonomi adalah tercapainya stabilitas ekonomi. Karena tercapainya stabilitas ekonomi mampu memudahkan jalannya kegiatan-kegiatan pembangunan ekonomi. Dalam tugas ini, tidak hanya kebijakan fiskal tetapi kebijakan moneter juga turut andil. Al-Kharj (pajak) yang merupakan kebijakan fiskal mempunyai fungsi stabilitas, yang mana dana pajak digunakan untuk stabilitas harga dalam menekan inflasi. Pajak merupakan kontribusi wajib yang dibayarkan kepada Negara yang terutang oleh perseorangnya atau badan yang bersifat memaksa. Jika instrument kebijakan ini diterapkan dengan baik, akan besar inputnya. Abu Yusuf Ya'qub adalah salah satu ilmuwan yang berkontribusi besar dalam pemikiran ekonomi Islam. Salah satu pemikiran yang beliau tulis dalam kitabnya Al-Kharaj adalah petunjuk bagaimana dalam mengelola pajak yang baik dan benar untuk mencapai kesejateraan umat. Perlu kiranya dikaji ulang bagaimana pemikiran Abu Yusuf tentang instrument Al-Kharj dalam stabilitasi moneter dan relevansinya di Indonesia. 
Syamsuri. 2020. Stabilitasi Moneter Melalui Instrumen Al-Kharj dan Relevansinya di Indonesia Menurut Abu Yusuf. Jurnal Syarikah 6 (2): 171 -181.

\section{PENDAHULUAN}

Berjalannya fungsi pemerintahan yang baik dapat dilihat dari kemampuan pemerintah dalam mengemban salah satu tugas penting dalam bidang ekonomi, yakni tercapainya stabilitas ekonomi. Dengan tercapainya stabilitas eknoki kegiatankegiatn pembangunan lebih mudah untuk dijalankan. Stabilitas ekonomi ini diusahakan dengan berbagai cara, tapi hampir pasti bersinggungan dengan kebijakan fiskal maupun moneter.(Yustika and Sulistiani 2010)

Kebijakan moneter berhubungan dengan pengendalian ekonomi yang memakai instrument suku bunga, inflasi, uang beredar, nilai tukar dan lain sebagainya. Semnetara itu, kebijakan fiskalmeliputi penerimaan dan belanja Negara (Syamsuri and Prastyaningsih, 2018). Tujuan kebijakan ini mengarah pada perbaikan kondisi perekonomian masyarakat untuk jadi lebih baik (Riza, 2017). Pajak merupakan salah satu instrument dari kebijakan ini, pajak sendiri adalah kontribusi wajib yang dibayarkan kepada Negara yang terutang oleh perseorangnya atau badan yang bersifat memaksa.

Di beberapa negara pemungutan pajak mengacu pada system Self Assesment. Sistem ini merupakan sistem pemungutan pajak yang memberi wewenang, kepercayaan, tanggung jawab kepada pihak wajib pajak untuk menghitung, memperhitungkan, membayar dan melaporkan sendiri besarnya pajak yang harus dibayar. Pemungutan pajak ini juga harus ada pengawasan yang ketat dari aparatur pajak, jika tidak akan terjadi penyelewengan yang menyebabkan pendapatan pajak tidak efisien. Sesuai dengan sistem ini, setiap wajib pajak wajib membayar pajak yang terutang sesuai dengan ketentuan peraturan perundangundangan perpajakan, dengan tidak menggantungkan pada adanya surat ketetapan pajak. (Fauzan, 2017)

Abu Yusuf Ya'qub adalah salah satu ilmuan yang berkontribusi besar dalam pemikiran ekonomi Islam. Beliau sangat berpengaruh pada masa kejayaan Daulah Abbasiyah. Beliau juga banyak menuangkan pemikirannya dalam berbagai teori ekonomi maupun konsep keuangan publik, pemikiran beliau ini beliau tulis dalam buku dengan judul al-kharaj. Buku ini merupakan pedoman untuk membuat kebijakan terkait pajak tanah (kharaj) pada masa pemerintahannya. (Santosa, 2015)

Pada masa kejayaan Daulah Abbasiyah, Abu yusuf sangat menekankan pengawasan ketat terhadap para pemungut pajak, untuk menghindari terjadinya penyelewengan seperti korupsi dll. Dalam hal ini, Abu Yusuf menggunakan prinsipprinsip yang dikenal dengan canon of taxation (Fauzan, 2017). Yakni kesanggupan membayar, pemberian waktu yang longgar bagi pembayar pajak, sentralisasi pembuatan keputusan dan administrasi pajak. Hal ini yang ditekankan Abu Yusuf.

Berdasarkan uraian yang telah dikemukakan diatas maka yang menjadi perumusan masalah dalam penelitian ini adalah bagaimana pemikiran Abu Yusuf tentang stabilitas moneter dengan instrument al-kharj dan relevansi di Indonesia?

\section{MATERI DAN METODE}

\section{Biografi Abu Yusuf Ya'qub}

Beliau bernama lengkap Ya'qub bin Ibrahim bin Habib bin Khunais bin Sa'ad AlAnshari Al-Jalbi Al-Kufi Al-Baghdadi. Dilahirkan di Kufah pada tahun 113 (731 M) dan meninggal dunia di Baghdad pada 
tahun 182 H (798 M). Ia berasal dari suku Bujailah, salah satu suku Arab. Keluarganya disebut Anshor karena dari pihak ibu masih mempunyai garis keturunan dengan kaum Anshor (pemeluk Islam pertama dan penolong Nabi Muhammad SAW) (Aravik, 2019). Beliau merupakan seorang ulama yang memiliki keilmuan yang sangat luas tentang berbagai persoalan kehidupan. Karna Abu Yusuf menimba berbagai ilmu kepada banyak ulama besar, salah satu gurunya adalah $\mathrm{Abu}$ Hanifah pendiri mazhab Hanafi. Dengan latar belakang Fuqaha yang beraliran ahl ar-ra'yu, Abu Yusuf cenderung memaparkan pemikirannya dengan menggunakan qiyas yang selalu didahului dengan pengkajian terhadap Al-Qur'an, Hadis Nabi, atsar shahabi, dan juga praktik penguasa yang shalih. Landasan pemikirannya adalah perwujuddan dari al-maslahah al-'ammah (kemaslahatan umum).(Tilopa, 2017)

Salah satu karya Abu Yusuf yang sangat fenomenal sepanjang sejarah adalah Kitab Al-Kharj (buku tentang perpajakan). Kitab Al-Kharj ditulis ketika kekhalifahan Harun Ar-Rasyid, penulisan kitab ini ditulis atas dasar perintah dan pertanyaan khalifah Harun Ar-Rasyid. Kitab ini juga mempunyai orientasi birokratif, karena penulisannya untuk merespon permintaan khalifah Harun Ar-Rasyid dan menjadikan buku ini petunjuk administratif untuk mengelola lembaga Baitul Mal dengan baik dan menjadikan Negara dalam keadaan makmur dan masyarakat tidak terdzalimi.(Tilopa, 2017)

\section{Pajak}

Ada berbagai pengertian ataupun definisi tentang pajak yang diberikan para ahli, khususnya para ahli dalam bidang keuangan Negara (public finance), ekonomi maupun hukum. Pajak sendiri dalam istilah bahasa asing disebut dengan tax (Inggris); import contribution, taxe, droit (Prancis); steuer, abgabe, gebuhr (Jerman); impuesto contribution, gravamen, tribute, tasa (Spanyol), belasting (Belanda) dan dalam literature Amerika dikenal dengan istilah tariff (Rasmini n.d.). Sedangkan secara etimologi dalam bahasa arab disebut dengan istilah daribah, yang berasal dari "daraba", "darban" yang mempunyai arti mewajibkan, menetapkan, menentukan, memukul, menerangkan ataupun membebankan (Fauzan, 2017). Pajak merupakan kewajiban atas harta setelah zakat, sehingga pelaksanaannya akan dirasakan sebagai sebuah beban.

Menurut Yusuf Qardhawi dalam kitabnya Fiqh Az-Zakah, Pajak merupakan kewajiban yang ditetapkan oleh wajib pajak, harus disetorkan kepada Negara sesuai dengan ketentuan tanpa mendapat prestasi kembali dari Negara dan hasilnya untuk membiayai pengeluaran pengeluaran umum disatu pihak dan untuk merealisasi sebagian tujuan ekonomi, sosial, politik dan tujuan-tujuan lain yang ingin dicapai oleh Negara.

Dalam Undang-Undang republik Indonesia Nomor 28 tahun 2007 tentang Ketentuan Umum dan Tata cara Perpajakan (KUP), Pajak merupakan kontribusi wajib kepada Negara yang terutang oelh perseorangannya ataupun badan yang bersifat memaksa berdasarkan UndangUndang, dengan tidak mendapatkan imbalan secara langsung dan digunakan untuk keperluan Negara.

Konsep pajak sudah diterapkan sejak zaman Rasulullah pada masa pemerintahannya. Rasulullah menerapkan jizyah (pajak), pajak ini dibebankan kepada orang-orang yang non-muslim, khususnya ahli kitab sebagai jaminan keselamatan jiwa, harta milik, kebebasan menjalankan ibadah serta pengecualian dari wajib militer. Selain itu Rasulullah juga menerapkan sistem Kharj, yakni sistem pajak tanah yang dipungut dari kaum nonmuslim ketika wilayah Khaibar ditaklukan. Tanah hasil penaklukan diambil alih oleh kaum muslimin dan pemilik lama diberikan hak untuk mengolah tanah tersebut dengan status penyewa dan memberikan setengah hasil produksinya kepada Negara.

Maka dalam perkembangannya Kharj (pajak) menjadi sumber pesmasukan Negara. Tujuan pajak itu sendiri 
mempunyai hubungan erat dengan tujuan Negara dan berakar pada tujuan masyarakat, yakni suatu cita-cita hidup yang tumbuh dan terkandung pada masyarakat untuk dicapai dan direalisasi oleh Negara sebagai alat perjuangan dan organisasi masyarakat. Tujuan inilah yang akan menjadi filasat bangsa dan filsafat Negara, dan tanpa tujuan ini tidak akan mungkin dapat mengerjakan tugasnya yang selaras dengan apa yang telah menjadi tujuan masyarakat.(Torry 2016).

\section{Fungsi Pajak}

Dalam fungsinya pajak dibagi menjadi empat, yakni: (Pajak, 2020)

a. Fungsi Budgetair (fungsi penerimaan)

Sama halnya dalam perekonomian rumah tangga, dalam perekonomian Negara juga mengenal sumber-sumber penerimaan dan pos-pos pengeluaran. Karena pajak adalah sumber utama penerimaan Negara, tanpa pajak sebagian besar kegiatan akan sulit untuk dilaksanakan.

b. Fungsi Redistribusi pendapatan

Pajak yang sudah dipungut akan digunakan lagi untuk kepentingan umum, yang juga termasuk membiayai pembangunan. Dengan hal itu akan meningkatkan lowongan pekerjaan yang pada akhirnya meningkatkan pendapat masyarakat. (Fauzan, 2017)

c. Fungsi Regulerend (mengatur)

Disini pajak berfungsi sebagai alat pengatur ataupun pelaksana kebijakan pemerintah dalam bidang sosial dan ekonomi. Dengan ini, pemerintahh memiliki dana untuk menjalankan kebijakan yang berhubungan dengan stabilitas harga sehingga inflasi dapat dikendalikan. Hal tersebut dapat dilakukan dengan mengatur peredaran uang di masyarakat, pemungutan dan penggunaan pajak yang efektif dan efisien.

d. Fungsi Stabilitas

Pemerintah menggunakan pajak sebagai dana untuk menjalankan kebijakan yang berhubungan dengan stabilitas harga sehingga inflasi dapat dikendalikan. Hal ini bisa dilakukan dengan mengatur peredaran uang di masyarakat, pemungutan pajak, penggunaan pajak yang efektif dan efisien. (Fauzan, 2017)

\section{Stabilitas Moneter}

Moneter merupakan bagian ilmu ekonomi yang mempelajari tentang sifat dan juga pengaruh uang terhadap kegiatan ekonomi. Banyak aspek yang dibahas dalam kajian ini, anatara lain: peranan dan fungsi uang, sistem moneter dan pengaruhnya terhadap jumlah uang dan kredit, struktur dan fungsi bank, pengaruh uang dan kredit terhadap kegiatan ekonomi dan lain sebagainya.

Sebagai salah satu instrument kebijakan ekonomi makro, kebijakan moneter memiliki peran yang sangat penting dalam penyelesaian krisis ekonomi yang sedang terjadi di Indonesia (Sriyono, 2016). Melalui kebijakan ini, pemerintah dapat mempertahankan kemampuan ekonomi untuk tumbuh sekaligus menekan inflasi.

Pemerintah mempunyai kebijakan sendiri untuk mengelola roda perekonomian, yang termasuk didalamnya mengatur hal yang terkait dengan standar moneter/ standar mata uang. Tugas dan fungsi pemerintah mengenai keuangan publik yakni terkait perlunya penetapan beban pajak yang rendah pada masyarakat dengan penerimaan pajak. (Hadi and Romli, 2020)

Stabilitas ekonomi sendiri dalam suatu negara dapat dilaksanakan dengan andil kebijakan moneter maupun kebijakan fiskal. Pajak sendiri yang merupakan instrument kebijakan fiskal, yang mempunyai fungsi menjalankan stabilitas harga sehingga dapat mengendalikan inflasi.

\section{Metodologi Penelitian}

Metode yang digunakan dalam penelitian ini adalah metode kualitatif dengan hasil penyajian dengan bentuk deskriptif, yakni dengan mengumpulkan data-data aktual dengan melaksanakan studi kepustakaan dari beberapa literatur 
tertulis. Penelitian ini menggunakan jenis penelitian library research (penelitian kepustakaan). Penelitian kepustakaan yakni penelitian yang menggunakan datadata tertulis seperti buku, kitab, majalah, jurnal dan lain-lain. Untuk mendapatkan data-data tersebut

\section{HASIL DAN PEMBAHASAN}

\section{Pemikiran Abu Yusuf Ya'qub dalam Pengelolaan Pajak}

Kekuatan utama pemikiran Abu Yusuf adalah masalah keuangan publik. Dengan daya observasi dan analisisnya, beliau menguraikan masalah keuangan dan menunjukkan berbagai kebijakan yang harus diabdosi untuk pertumbuhan ekonomi dan kesejahteraan masyarakat. Untuk itu dalam perpajakan Abu Yusuf memberikan prinsip-prinsip tentang kesanggupan pembayaran pajak, pemberian tenggang waktu dalam pembayaran pajak dan juga sentralisasi pembuatan keputusan dalam administrasi pajak.(Tilopa, 2017)

Selain itu dalam konsep pajak yang dikembangkan oleh Abu Yusuf, pajak dapat dipungut dengan catatan bahwa dilakukan dengan landasan keadilan dan kemurahan, serta tidak memberatkan ataupum membebani. Dalam landasan kemaslahatan tentang pemungutan pajak sebagaimana yang disampaikan oleh Al-Maliki dalam Fahmi:(Mulyana et al., 2017)

"Karena menjaga kemaslahatan umat melalui berbagai sarana-sarana seperti keamanan, pendidikan, dan kesehatan adalah kewajiban, sementara itu jika kas Negara tidak mencukupi untuk membiayai hal tersebut, maka pajak itu menjadi wajib. Walaupun demikian, syara' mengharamkan Negara menguasai harta benda rakyat dengan kekuasaannya. Karena jika Negara mengambilnya dengan menggunakan kekuatan dan cara paksa, berarti itu merampas. Sedangkan merampas hukumnya haram."

Maka pajak dalam konsep syariat tidak boleh dipungut secara paksa dan dengan kekuasaan, melainkan menjadi kewajiban bagi umat Islam dalam memelihara kemaslahatan umat dan mencegah kemudharatan yang lebih besar. Oleh karena itu, menurut Abu Yusuf dalam hal penetapan pajak, ia menyetujui Negara mengambil bagian hasil pertanian dari penggarap daripada menarik sewa lahan pertanian. Hal ini lebih adil dan memberikan kemudahan dalam memperluas tanah garapan.

Dalam pandangannya, Abu Yusuf menyatakan bahwa sumber pendapatan Negara berasal dari dua sumber, untuk sumber pertama bersifat permanent revenue dan berasal dari:

a. $\mathrm{Fa}^{\prime} \mathrm{i}$

Merupakan harta yang diperoleh orang Islam tanpa melalui peperangan baik dengan pasukan berkuda ataupun yang lainnya. Seperlima harta fa'i diberikan kepada orang-orang yang berhak sebagaimana yang dijelaskan dal AlQur'an surat Al-Hasyr:7. Harta ini merupakan sumber dana umum yang diperuntukkan bagi Rasul dan pemerintah serta pihak lain yang bertugas untuk mewujudkan kemaslahatan kehidupan kaum muslimin. (Muhammad Fauzan, 2017)

b. Usyur (Bea Cukai)

Merupakan pajak yang dikenakan atas barang-barang dagangan yang masuk ke wilayah muslim. Pemungutan usyur dilakukan pertama kali pada zaman khilafah Umar bin Khattab. Usyur dibebankan kepada pedagang muslim yang mengambil barang dagangan dari daerah nonmuslim. Begitu juga sebaliknya, pedagang nonmuslim akan dikenakan pemungutan Usyr jika ingin masuk ke daerah perdagangan muslim. Dalam pemungutannya Abu Yusuf mengisyaratkan dua hal yang harus dipertimbangkan, yakni: 
a) Barang-barang yang dimaksudkan adalah barangbarang dagangan

b) Nilai barang dagangan tidak kurang dari 200 dirham.(Tilopa, 2017b)

c. Jizyah

Jizyah adalah kewajiban yang dibebankan kepada penduduk non muslin yang tinggal diNegara Islam sebagai pengganti biaya perlindungan hidp, property dan kebebasan untuk menjalankan agama mereka. Untuk jenis pendapatan ini Abu Yusuf, menyarabkan untuk menempatkan seorang administrator yang jujur di setiap kota agar pemungutan jizyah berjalan efektif dan tetap berprinsip pada nilai-nilai keadilan.(Tilopa, 2017b)

d. Pajak Tanah (Kharaj)

Kharaj menurut bahasa berarti alkara' (sewa) dan al-ghullal (hasil).(Muhammad Fauzan, 2017) Dan pajak dalam artian lain merupakan harta yang dikeluarkan oleh pemilik tanah untuk diberikan kepada Negara. Al-Kharaj juga bisa diartikan dengan apa yang dibayarkan untuk pajak tanah pertanian untuk pajak hasil bumi. Dana yang terkumpul ini akan digunakan untuk penyelenggaraan Negara, dana cadangan dan juga santunan fakir miskin dan janda. Kemudian untuk menghindari hal yang tidak diiginkan, dana untuk menggaji aparat pemerintah yang bertugas terhadap Negara diambil dari dana baitul maal dan tidak dari dana Kharaj. Hal ini berlandaskan dalil dalam surat Al-Hasyr ayat 710.(Syamsuri and Prastyaningsih, 2018b)

Berkaitan dengan pemungutan kharaj, terbagi menjadi dua macam:(Oky, 2019)

1) Kharaj menurut perbandingan (muqasimah) merupakan kharaj perbandingan yang ditetapkan porsi hasil seperti setengah atau sepertiga hasil dari itu, umumnya dipungut setiap kali panen.

2) Kharj tetap (wazifah) merupakan beban khusus pada tanah sebanyak hasil alam ataupun uang persatuan lahan. Kharaj tetap ini menjadi wajib setelah lampau satu tahun.

Maka penetapan kharaj menurut Abu Yusuf, cenderung menyetujui Negara mengambil bagian dari hasil pertanian dari pada menarik sewa dari lahan pertanian. Selain itu Abu Yusuf lebih merekomendasikan penerapan muqasamah (proposal tax) dari pada misahah (fixed tax) yang telah berlaku sejak masa khalifah Ummar hingga periode awal dinasti Abassiyah.(Muhammad Fauzan, 2017) Beliau menilai sistem pajak muqasamah lebih adil dan tidak memberatkan bagi para petani sedangkan sistem pajak tetap (misahah) tidak memiliki ketentuan apakah harus ditarik dalam jumlah uang atau barang. Konsekuensinya, apabila terjadi fluktuasi harga bahan makanan, antara perbendaharaan Negara dengan para petani akan saling memberikan pengaruh positif. Maka dari itu Abu Yusuf berpendapat metode pajak yang proporsional (muqasamah) dapat dilakukan untuk meningkatkan pemasukan Negara dan meningkatkan hasil produksi pertanian. Sesuai dengan pandangan Abu Yusuf:

"Dalam pandangan saya, sistem perpajakan terbaik untuk menghasilkan pemasukan lebih banyak bagi keuangan Negara dan yang paling tepat untuk menghindari kedzaliman terhadap para pembayar pajak oleh para pengumpul pajak adalah pajak pertanian secara proposional. Sistem ini akan menghalau kedzaliman terhadap para pembayar pajak dan menguntungkan keuangan Negara."

Selain itu Abu Yusuf juga menekankan perihal pentingnya menunjuk administrator pajak yang amanah dan tidak koruptif. Mereka harus bekerja secara professional dan menganjurkan 
pengambilan gaji diambil dari baitul mal dan bukan dari pembayar kharaj langsung. Hal ini dilakukan untuk menghindari terjadinya tindakan penyuapan dengan pihak wajib pajak dan korupsi. Bahkan beliau menyarakankan diadakannya penyelidikan terhadap para pemungut pajak. Adapun usulan perbaikan administrasi perpajakan adalah sebagai berikut:(Aravik, 2019)

Tingkat beban pajak harus lebih rendah dan adil, karna jika tidak akan melemahkan tingkat produksi petani dan dengna sendirinya mengurangi penerimaan Negara

a. Pengumpulan pajak yang melalui perantara dilakukan dengan cara yang beradab

b. Beban pajak seharusnya ditentukan oleh pemerintah pusat sebab pemberian otoritas kepada pemerintah lokal dan kolektor pajak akan menyebabkan penyalahgunaan wewenang. Dan demikian juga dengan kolektor pajak tidak dibebankan menerima pemberian apa pun dari pembayar pajak.

c. Pengumpulan pajak melalui perantara harus dihindarkan. Karena dapat menimbulkan tindakan-tindakan yang salah dan berlebihan sehingga akan mengganggu aktivitas pertanian dan mengurangi hasil panen yang berakibat penerimaan Negara berkurang dan kesejahteraan sosial merosot.

d. Para pengepul pajak seharusnya dari orang-orang yang jujur dan terpercaya. Kriteria mereka harus diawasi dan setiap penyelewengan harus ditindak. Oleh karena itu, para kolektor pajak harus paham sepenuhnya hukumhukum perpajakan.

Pemikiran Abu Yusuf diatas dimaksudkan untuk pencapaian tujuan kesejahteraan sosial yang didasarkan pada aturan-aturan Islam. Apabila keadilan sudah ditegakkan dan segala tindakan tirani dihilangkan, maka keselamatan dan kemakmuran akan terwujud yang akan disertai dengan keberkahan Allah. Sehingga pembangunan ekonomi dapat menumbuhkan kesejahteraan material dan spiritual bagi seluruh lapisan masyarakat.

\section{Relevansi Pemikiran Abu Yusuf Tentang Al-Kharj di Indonesia}

Indonesia merupakan Negara berkembang yang ingin menjadi negara maju, dan sedang gencar-gencarnya melaksanakan agenda pembangunan di berbagai sektor. Hal ini bertujuan untuk meningkatkan kesejahteraan ekonomi masyarakat. Maka guna mencapai semua itu, pemerintah membutuhkan jumlah dana yang tidak sedikit.(Abdullah et al. 2016)

Dalam kaitannya tersebut, sumber penerimaan utama keuangan Negara adalah pajak. Maka pajak dalam struktur keuangan Negara mempunyai kontribusi yang sangat besar. Dewasa ini pajak memang ditetapkan menjadi kewajiban warga Negara dalam sebuah Negara.(Palopo et al., 2016) Putusan ini diambil dengan alasan karna dana pemerintah tidak mencukupi untuk pembiayaan berbagai pengeluaran Negara. (Rusydi, 2010)

Adapun dalam pandangan Abu Yusuf dalam kitab al-kharaj, konsep al-kharaj dan visi strategisnya terhadap kebijakan sumber pendapatan negara menggambarkan keunggulan dan pengalaman beliau dalam bidang ekonomi dan

Abu Yusuf menerangkan dalam kitabnya al-kharj, bahwa pendapatan negara menurut anggaran pendapatan di Indonesia dengan pendapatan Negara menurut al-kharaj tidak jauh berbeda.

\section{a. Self Assesment atau Sistem Qabalah}

Pemungutan pajak dengan prinsip self assessment bisa diartikan memberikan kepercayaan dan tanggungjawab kepada wajib pajak untuk menghitung, membayar dan juga melaporkannya secara mandiri jumlah besaran pajak yang harus dibayar.Sedangkan sistem Qabalahmerupakan sistem yang sempat dijalankan sebelumnya, tetapi sistem ini banyak menyebabkan terjadinya kedzaliman dimasyarakat. Sistem ini adalah sistem pemungutan kharaj 
pemerintah untuk bertanggaung jawab dalam pemungutan kharaj di wilayahnya.(Oky, 2019)

Maka Abu Yusuf memberikan solusi untuk pemerintah agar memiliki lembaga khusus yang mengatur tantang pajak dan memiliki petugas pajak yang professional. Sistem yang disarankan oleh Abu Yusuf relevan jika diterapkan pada masa sekarang. Karna sistem self assessment yang saat ini berlaku di Indonesia memungkinya terjadi kecurangan oleh wajib pajak.

\section{b. Barang tambang atau Rikhaj}

Pemegang operasi produksi untuk hasil pertambangan minela logam dan batubara diwajibkan yntuk membayar $4 \%$ pada pemerintah dan membayar $6 \%$ pada pemerintah daerah dari keuntungan bersih sejak melakukan aktifitas produksi. Sehingga jika dijumlahkan semuanya pajak pertambangan mencapai $10 \%$. Hal ini dirangkum pada peraturan pasal 129 UU No. 4 Tahun 2009 tentang pertambangan mineral dan batu bara.

Melihat potensi Indonesia sebagai Negara yang kaya akan sumber dayanya (baik itu didarat maupun dilaut). Maka seharusnya rakyat merasakan kemakmuran Negara. BUMN dan BUMD yang bertugas mengelola sumber daya alam, seharusnya memberikan royalati penuh pada Negara. Begitu pula BUMS yang bertugas mengelola kekayaan alam berupa pertambangan di Indonesia dan dibebankan pajak sebesar 20\%. Tetapi kenyataan yang terjadi sampai saat ini, pihak-pihak tersebut malah membebani dan merugikan Negara. Dan hal tersebut yang membuat kemaslahatan masyarakat berkurang.

Jika pemerintah berani menerapkan konsep pajak pertambangan seperti yang dijelaskan Abu Yusuf, yakni pemungutan pajak sama dengan rikhaj 1/5. Maka tidak menutup kemungkinan jika pendapatan Negara akan melampaui target dan dapat menjadi surplus anggaran, tidak seperti sekarang yang sering terjadi defisit anggaran.

\section{c. PBB atau Kharj}

Pajak bumi dan bangunan pertama diatur pada UU No. 12 Tahun 1985 yang kemudian diubah dalam UU No.12 Tahun 1994. Dalam PBB terdapat NJOP yang merupakan harga rata-rata uang didapatkan dari transaksi jual-beli yang terjadi secara wajar. NJOP ini dijadikan dasar pengenaan pajak setiap tiga tahun sekali sesuai dengan yang ditentukan oleh menteri keuangan.

Dalam kaitannya Abu Yusuf menuliskan perbedaan antara PBB dan perbedaan dengan al-kharaj. PBB untuk semua jenis tanah dan al-kharaj untuk lahan pertanian. Perbedaan lainnya adalah pada hukum asal al-kharj yakni pengenaan pajak tanah yang dikelola orang kafir yang kalah perang dan tidak masuk Islam. Sedangkan PBB diperuntukkan untuk semua masyarakat Negara yang memiliki objek pajak bumi dan bangunan.

Adapun tarif dari PBB adalah $0.5 \%$ dari objek pajak sedangkan dengan 26,112 $\mathrm{kg}$ gandung. Dan apabila dengan sistem muqasamah yakni 2/5 jika irigasi atau 1/5,5 jika membutuhkan biaya. Selanjutnya konsep al-kharaj yang sudah dijelaskan oleh Abu Yusuf dan sistem muqasamah yang diterapkan di Indonesia yang karakternya adalah Negara agraris, untuk itu pendapatan Negara ini dari sector pertanian sangatlah professional.

\section{d. Beacukai atau Usyur}

Pajak bea cukai dalam istilah $\mathrm{Abu}$ Yusuf adalah usyur dan pertama kali diterapkan pada masa khalifah Umar bin Khattab. Pada masa itu Musa Al-Asari menulis surat kepada khalifah Umar bin Khattab tentang pedagang kaum muslim yang mendatangi wilayah kafir harbi dan dikenakan usyur 1/10. Maka khalifah memerintahkan Abu Musa untuk mengambil jumlah pajak yang sama dari mereka, dari ahli dzimih 5\% dan dari pedagang muslim $2,5 \%$ dengan batas minimal barang mencapai 200 dirham.(Oky, 2019)

Ushur merupakan pajak yang diambil dari dagangan yang masuk kewilayah 
muslim. Sementara itu, berdasarkan UU No. 19 tahun 1995 yang telah diubah menjadi UU no. 17 tahun 2006 tentang bea cukai (kepabean).Pengertian bea sendiri adalah suatu pungutan yang dikenakan atas suatu kejadian dan perbuatan yang berupa lalu lintas barang dan perbuatan lainnya atas ketentuan peraturan undang-undang. Sedangkan cukai merupakan pungutan Negara yang dikenalkan terhadap barangbarang tertentu yang mempunyai sifat dan karakteristik yang ditetapkan undangundang, yakni barang-barang yang pemakaiannya perlu dibatasi ataupun diawasi karena telah melekat hak-hak Negara.

\section{e. Tarif Proposional dengan Muqasamah}

Metode pajak yang proporsional menurut Abu Yusuf bisa memberikan peningkatan pendapatan Negara dari segi pajak tanah dan bisa mendorong para petani dan meningkatkan produksinya. Sistem ini dinilai memberikan rasa adil dan menjadi automatic stabilizier untuk perekonomian sehingga dalam waktu panjang perekonomian tidak akan berfluktuasi terlalu tajam. Maka bisa dilihat bahwa dari penjelasan diatas, menunjukkan Abu Yusuf juga menginginkan keadilan bagi seluruh warga Negara. Kemudian dalam penarikan pajak, macamnya sangat beragam; ada tarif progresif yang diterapkan pada $\mathrm{PPh}$ dan juga tarif proporsional yang diterapkan pada PBB dan PPN.(Oky, 2019)

Menurut Abu Yusuf tujuan pemungutan pajak bumi (kharaj) adalah "umurul nafi' lijama'atihim" yang berarti memberi manfaat untuk masyarakat, maka pajak bumi (kharj) diharapkan bisa mendatangkan kenikmatan kepada seluruh masyarakat baik secara langsung maupun tidak langsung.(Purbayu Budi Santosa, 2015)

Pajak sendiri mengatur interaksi antara manusia dengan manusia lainnya (mua'amalah), hal ini merupakan dari syari'at Islam.(Abdullah et al., 2016) Tanpa adanya petunjuk syariat dalam perpajakan, pajak dapat dijadikan sebagai alat penindas rakyat. Jika tidak ada batasan pemungutan pajak oleh syariat, maka pemerintah akan menetapkan dan memungut pajak sesuka hati dan menggunakannya menurut apa yang dikehendakinya.(Sodiq 2015)

Pajak yang sesuai syariah, diharapkan mambu membuat kaum muslim berlombalomba membayar pajak sebagai salah satu bentuk jihad mereka dalam mengentas beban bersama.Aturan mengenai perpajakan harus berpedoman pada AlQur'an, Hadist, Ijma' dan Qiyas. Jika pemungutan pajak tidak sesuai syari'at, maka hal itu tidak diperkenankan dan dilarang oleh Rasulullah. Sebagaimana hadist yang berarti "Tidak masuk Surga petugas pajak yang dzalim", (HR. Abu Daud).(Abdullah et al., 2016) Sejumlah fuqaha dan ekonom Islam telah menyatakan, bahwa sahnya pemungutan pajak dibolehkan dengan alasan kemaslahatan umat

\section{KESIMPULAN DAN IMPLIKASI}

Abu Yusuf berpendapat bahwasannya sumber penerimaan dari kebijakan fiskal berasal dari berbagai jenis perpajakan seperti ushr, jizyas, kharaj, dan fa'i. Sedangkan dengan penetapan pajak, Abu Yusuf cenderung menyetujui Negara mengambil bagian dari hasil pertanian dari pada menarik sewa dari lahan pertanian. Selain itu Abu Yusuf lebih merekomendasikan penerapan:

a. Sistem Self assessment yang diterapkan di Indonesia hamper sama dengan Qabalah yang dijelaskan Abu Yusuf. Akan tetapi penggunaan sistem self assessment dibatasi pemerintah.

b. Pemerintah haruslah berani ekstensifikasi dan diversifikasi pajak, terutama dibidang pertambangan yang mempunyai potensi sangat besar. Banyak perusahaan yang mengeruk kekayaan alam Indoensia, akan tetapi mereka membayar pajak relative kecil. Karna pajak pertambangan sama dengan rikhaj yakni 1/5. 
c. Pajak kharaj yang berdasarkan tingkat kesuburan di Indonesia dama dengan PBB yang berdasarkan luas wilayah dan NJOP. Kalau sistem kharaj ini dilaksanakan di Indoensia maka potensi pajak dari PBB lebih besar karna Indoensia Negara agraris.

d. Usyur yang diterapkan di Indonesia merupakan bea cukai. Tetapi dengantidak ada pembeda hanya berdasarkan kepemilikan objek pajak.

e. Tarif pajak muqosamah yang dikemukakan Abu Yusuf atau Tarif pajak proposioanl yang sudah diterapkan di Indonesia, seperti pajak PP maupun PPN. Tetapi penerapan pajak pertahanan belum menyeluruh

\section{DAFTAR PUSTAKA}

Abdullah, M Wahyuddin et al. 2016. "TAX AMNESTY DALAM BINGKAI MAQASHID AL- SYARI'AH MAQASHID AL- SYARI'AH' $S$ VIEW OF TAX AMNESTY." 4: 1-8.

Aravik, Havis. 2019. "Havis Aravik Dosen Sekolah Tinggi Ekonomi Dan Bisnis Syariah Indo Global Mandiri ( STEBIS IGM ) Palembang." 2(August 2016): 29-38.

Hadi, Sholikul, and Moh. Romli. 2020. "Relevansi Konsep Uang Dalam Perspektif Ibnu Khaldun Terhadap Kebijakan Moneter Di Indonesia." AlKharaj : Jurnal Ekonomi, Keuangan \& Bisnis Syariah 2(2): 174-88.

Muhammad Fauzan. 2017. "Konsep Perpajakan Menurut Abu Yusuf." Human Falah 4(2): 175.

Mulyana, Mumuh et al. 2017. "Plagiarism Scan Report." Jurnal Ekonomi Islam, FAI Universitas Muhammadiyah Prof. Dr. Hamka 5(2): 3-5. http://repository.uinsuska.ac.id/9546/1/2012_201207AF. pdf.

Oky, Rachmatullah. 2019. "Iqtishoduna: Jurnal Ekonomi Islam." Iqtishoduna: Jurnal Ekonomi Islam 8(1): 1-32. http://ejournal.iaisyarifuddin.ac.id/i ndex.php/iqtishoduna/article/view/ 340.

Pajak, Direktorat Jenderal. 2020. "Fungsi Pajak Direktorat Jenderal Pajak." Www.Pajak.Go.Id.

Palopo, Iain et al. 2016. "2.Sakirman_fix." 1(1): 17-28.

Purbayu Budi Santosa, Aris Anwaril Muttaqin. 2015. "MASHLAHAH DALAM PAJAK TANAH PERSPEKTIF ABU YUSUF ( TELAAH TERHADAP KITAB AL-KHARAJ ) Aris Anwaril Muttaqin Dosen Ekonomi Islam Universitas Diponegoro." JDEB 12(2): 113-23.

Rasmini, Mas. "Dasar-Dasar Perpajakan." In Dasar-Dasar Perpajakan, , 1-41.

Riza, Muhammad. 2017. "MAQASHID SYARIAH DALAM PENERAPAN PAJAK KHARAJ PADA MASA UMAR BIN KHATTAB RA." JURNAL EKONOMI DAN BISNIS ISLAM 2(2).

Sodiq, Amirus. 2015. "KONSEP KESEJAHTERAAN DALAM ISLAM." Equilibrium Vol. 3, No: 380-405.

Sriyono, Sriyono. 2016. "STRATEGI KEBIJAKAN MONETER DI INDONESIA." JKMP (Jurnal Kebijakan dan Manajemen Publik) 1(2): 111.

Syamsuri, Syamsuri, and Ika Prastyaningsih. 2018a. "Upaya Pencapaian Kesejahteraan Masyarakat Melalui Pengelolaan Pajak: Relevansi Konsep Al Kharaj Abu Yusuf Di Indonesia." An-Nisbah: Jurnal Ekonomi Syariah 5(1).

-_- 2018b. "Upaya Pencapaian Kesejahteraan Masyarakat Melalui Pengelolaan Pajak: Relevansi Konsep Al Kharaj Abu Yusuf Di Indonesia." An-Nisbah: Jurnal Ekonomi Syariah 5(1): 236-56.

Tilopa, Martina Nofra. 2017a. "PEMIKIRAN EKONOMI ABU YUSUF DALAM KITAB AL-KHARAJ." AL-INTAJ 3(1): 154-71. . 2017b. "PEMIKIRAN EKONOMI ABU YUSUF DALAM KITAB AL-KHARAJ IAIN IB Padang Email: norapanai2@gmail.com A 
PENDAHULUAN Sejarah Merupakan Potret Manusia Di Masa Lampau , Ia Merupakan Laboratorium Kehidupan Generasi Zamannya , Setiap Begitupun Ada Menampilkan Pemiki." 3(1): 154-71.
Torry, pranoto dan ayub. 2016. "No Title." Yustisia 5(2): 395-414.

Yustika, Ahmad Erani, and Eka Heni Sulistiani. 2010. "Kebijakan Moneter, Sektor Perbankan, Dan Peran Badan Supervisi." Jurnal Keuangan dan Perbankan 14(3): 447-58. 